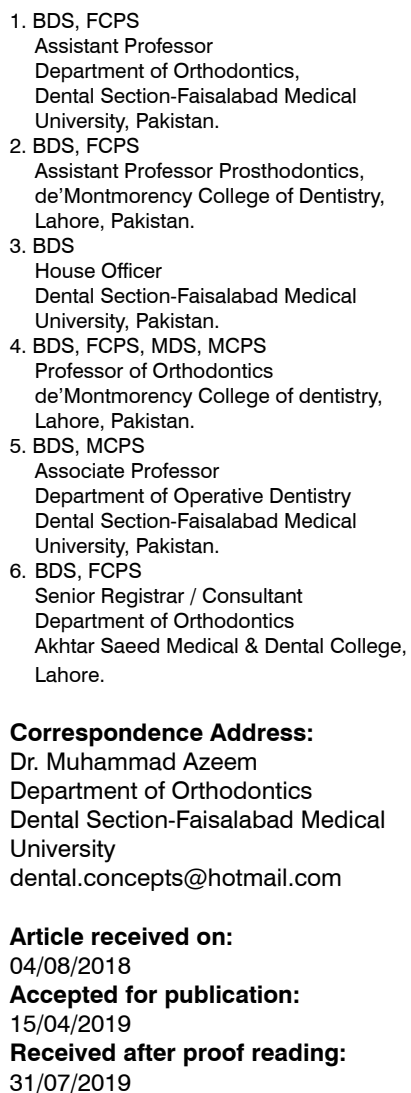

\section{LEARNING STRATEGIES OF DENTAL UNDERGRADUATES OF ORTHODONTICS AND PROSTHODONTICS.}

\begin{abstract}
Muhammad Azeem ${ }^{1}$, Momina Akram², Rubbab Asghar ${ }^{3}$, Arfan ul Haq ${ }^{4}$, Nadeem Tarique ${ }^{5}$, Saadia Ata ${ }^{6}$
ABSTRACT... It is very important for faculty members to know how students learn so that they can modify teaching methods accordingly. To measure the learning preferences of dental undergraduates at Faisalabad Medical University, Pakistan. Study Design: A Cross-sectional study. Setting: Orthodontic Department, Dental Section- Faisalabad Medical University, Faisalabad. Period: Session 2017-18. Materials and Methods: Present study was conceived on the final year dental undergraduates $(n=40)$ of Faisalabad Medical University, Pakistan to determine the learning preferences. Questionnaire was administered using Felder and Soloman's Index of Learning Styles. The descriptive statistics were applied and survey data were converted in to scores. Results: The results showed that most of the undergraduate dental students were verbal learners (50\%). On the sequential/global scale, $55 \%$ were balanced and $40 \%$ were sequential learners. On the active/reflective scale, $45 \%$ were balanced, and $30 \%$ were active. On the sensing/intuitive scale, $50 \%$ were balanced, and $38 \%$ were sensing. Conclusion: The undergraduate dental students were found to be mostly verbal learners.
\end{abstract}

Key words: Learning, Learning style, Learning strategy, Orthodontic, Reflection

Article Citation: Azeem M, Akram M, Asghar R, Arfan ul Haq, Tarique N, Ata S. Learning strategies of dental undergraduates of orthodontics and prosthodontics. Professional Med J 2019; 26(8):1311-1314.

DOI: 10.29309/TPMJ/2019.26.08.3875

\section{INTRODUCTION}

There are different types of learning styles. Efficient learning style is the one under which a dental student is most likely to learn. ${ }^{1}$ Learning style influences level of learning success. By knowing a particular learning style helps students to maximize their learning. ${ }^{2}$

There are different theories of learning. For example, Kolb's experimental learning theory, Donald Schon theory of reflection-in-action and reflection-on-action, and, Honey and Mumford classification. $^{3-6}$ There are various instruments to determine the learning styles. For example, Vermunt learning styles, VARK learning styles, Myers-Briggs learning styles, Greogorc learning styles and Felder and Soloman's learning styles' Index. ${ }^{7-10}$

According to the Felder and Soloman's Index, there are 4 types of learners i.e. active or reflective, visual or verbal, sensing or intuitive, and sequential or global. ${ }^{11}$ Active learners are type of learners that learn in groups while reflective learners prefer to learn alone. Visual learners are type of learners that learn by viewing diagrams while verbal learners prefer to learn by listening to lectures. Sensing learners are type of learners that learn by relating information with real world while intuitive learners prefer to be conceptual and innovative. Finally, sequential learners prefer to learn by following stepwise paths while global learners learn randomly.

It is very important for faculty members to know how students learn so that they can modify teaching methods accordingly. Due to the shortage of teachers it is very important to modify BDS curricula according to match dental students' preferences. Very few studies have been conceived to measure the learning preferences of dental undergraduates. ${ }^{12-15}$ The results of such studies will help in improvement of teaching methods and BDS curricula to match 
dental students' preferences.

Following this rationale, the objective of present study was to measure the learning preferences of dental undergraduates at Faisalabad Medical University, Pakistan.

\section{MATERIAL AND METHODS Study Design \\ A Cross-sectional study.}

\section{Setting}

Orthodontic Department, Dental SectionFaisalabad Medical University, Faisalabad.

\section{Period}

Session 2017-18.

Present study was conceived on the final year dental undergraduates $(n=40)$ of Faisalabad Medical University, Pakistan to determine the learning preferences. Questionnaire was administered using Felder and Soloman's Index of Learning Styles. ${ }^{11}$

Felder and Soloman's Index identify learners on four scales, active or reflective scale, visual or verbal scale, sensing or intuitive scale, and sequential or global scale. 1-3 score shows a well balanced learner. 5-7 score shows a moderate preference while score of 9-11 shows a strong preference for one dimension of the scale. ${ }^{11}$

The descriptive statistics were applied and survey data were converted in to scores. Chi-square test was applied to find gender and age differences.

\section{RESULTS}

Response rate was $100 \%$. The results showed that out of the 40 undergraduate dental students (Age 32.13 \pm 5.63 years) (35 Females, 5 males), most were verbal learners (50\%), $30 \%$ were visual learners and only $20 \%$ were mixture of visual and verbal learners. (Table-I)

On the sequential/global scale, 55\% were balanced, $40 \%$ were sequential learners while only $5 \%$ were global learners. On the active/reflective scale, $45 \%$ were balanced, $30 \%$ were active while
$25 \%$ were reflective learners. On the sensing/ intuitive scale, $50 \%$ were balanced, $38 \%$ were sensing while $12 \%$ were intuitive learners. Sex and age differences were statistically insignificant to the different Felder and Soloman's categories. (Table-I)

\begin{tabular}{|l|c|}
\hline Learning Strategy & Percentages \\
\hline \multirow{2}{*}{ Visual/Verbal } & $30 \%$ Visual learner \\
\hline \multirow{3}{*}{ Sequential/Global } & $20 \%$ Balanced \\
\cline { 2 - 2 } & $50 \%$ Verbal learner \\
\hline \multirow{2}{*}{ Active/Reflective } & $40 \%$ Sequential learner \\
\hline \multirow{2}{*}{ Sensing/Intuitive } & $55 \%$ Balanced \\
\hline \multirow{2}{*}{ Selobal learner } \\
\hline
\end{tabular}

Table-I. Distribution of learner types $(\mathrm{N}=40)$

\section{DISCUSSION}

The objective of present study was to measure the learning preferences of dental undergraduates at Faisalabad Medical University, Pakistan. The survey was conducted using Felder and Soloman's Index of Learning Styles. This is in contrast to the previous conducted studies on dental students where survey was conducted using VARK questionnaire. ${ }^{12-15}$

The results in the present study showed that most of the dental undergraduates were verbal learners. The results in the present study showed that on the sequential/global scale about half of the trainees were balanced, on the active/reflective scale more than half of the trainees were balanced and on the sensing/intuitive scale about half of the trainees were balanced. The study conducted on the Saudi dental students showed that most prevalent single learning preferences were aural preferences (20\%) followed by kinesthetic (15\%) preferences. ${ }^{12}$ The study conducted on the Polish dental students showed that most prevalent single learning preferences were aural preferences (24\%) followed by kinesthetic (18\%) preferences. ${ }^{13}$ Additionally, the study conducted on the Saudi dental students showed that most 
prevalent single learning preferences were aural preferences $(11.6 \%)$ followed by kinesthetic (8\%) preferences. ${ }^{14}$ By contrast, the study conducted on the USA dental students showed that most prevalent single learning preferences were read-write preferences $(20 \%)$ followed by visual (14.5\%) preferences. ${ }^{15}$

The results in the present study showed that sex differences were statistically insignificant to the different Felder and Soloman's categories. This is in agreement with the findings of other studies where no sex differences were found. ${ }^{15,16}$ This is however in contrast with the findings of study on physiology undergraduates where sex differences were found. ${ }^{17}$

Thus it was found that the undergraduate dental students were found to be mostly verbal learners. The results of the present study will help in improvement of teaching methods and BDS curricula to match dental students' preferences. It is suggested that teachers should broaden their range of teaching styles to match dental students' preferences. Further large scale multicentric studies are suggested.

\section{CONCLUSION}

- The undergraduate dental students were found to be mostly verbal learners and were balanced on other scales of Felder and Soloman's Index of Learning Styles.

- Most of the undergraduate dental students were verbal learners (50\%). On the sequential/ global scale, $55 \%$ were balanced and $40 \%$ were sequential learners. On the active/ reflective scale, $45 \%$ were balanced, and $30 \%$ were active. On the sensing/intuitive scale, $50 \%$ were balanced, and $38 \%$ were sensing.

Copyright@ 15 Apr, 2019.

\section{REFERENCES}

1. LeCun Y, Bengio $Y$, Hinton G. Deep learning. Nature. 2015 May; 521 (7553):436.

2. Zhu HR, Zeng $H$, Zhang $H$, Zhang HY, Wan FJ, Guo $\mathrm{HH}$, Zhang $\mathrm{CH}$. The preferred learning styles utilizing VARK among nursing students with bachelor degrees and associate degrees in China. Acta Paulista de Enfermagem. 2018 Mar; 31(2):162-9.
3. Truong HM. Integrating learning styles and adaptive e-learning system: Current developments, problems and opportunities. Computers in human behavior. 2016 Feb 1;55:1185-93.

4. Peterson K, DeCato L, Kolb DA. Moving and learning: Expanding style and increasing flexibility. Journal of Experiential Education. 2015 Sep; 38(3):228-44.

5. An D, Carr M. Learning styles theory fails to explain learning and achievement: Recommendations for alternative approaches. Personality and Individual Differences. 2017 Oct 1;116:410-6.

6. McKenna L, Copnell B, Butler AE, Lau R. Learning style preferences of Australian accelerated postgraduate pre-registration nursing students: A cross-sectional survey. Nurse education in practice. 2018 Jan 1; 28:2804.

7. Peyman H, Sadeghifar J, Khajavikhan J, Yasemi M, Rasool M, Yaghoubi YM, Nahal MM, Karim H. Using VARK approach for assessing preferred learning styles of first year medical sciences students: A survey from Iran. Journal of clinical and diagnostic research: JCDR. 2014 Aug; 8(8):GC01.

8. Martínez-Fernández JR, Vermunt JD. A cross-cultural analysis of the patterns of learning and academic performance of Spanish and Latin-American undergraduates. Studies in Higher Education. 2015 Feb 7; 40(2):278-95.

9. Willingham DT, Hughes EM, Dobolyi DG. The scientific status of learning styles theories. Teaching of Psychology. 2015 Jul; 42(3):266-71.

10. Czepula Al, Bottacin WE, Hipólito Jr E, Baptista DR, Pontarolo R, Correr CJ. Predominant learning styles among pharmacy students at the Federal University of Paraná, Brazil. Pharmacy Practice (Granada). 2016 Mar; 14(1):0-.

11. Çardak ÇS, Selvi K. The construct validity of FelderSoloman index of learning styles (ils) for the prospective teachers. Gaziantep University Journal of Social Sciences. 2016 Apr 1; 15(2).

12. Al-Saud LM. Learning style preferences of first-year dental students at King Saud University in Riyadh, Saudi Arabia: influence of gender and GPA. Journal of Dental Education. 2013 Oct 1; 77(10):1371-8.

13. Kaczmarek U, Smulczyńska A, Grzesiak-Gasek I. Learning styles of dentistry students. Dent Med Probl 2010; 47(2):193-8. 
14. Nuzhat A, Salem R, Quadri M, Al-Hamdan N. Learning style preferences of medical students: A singleinstitute experience from Saudi Arabia. Int $\mathrm{J}$ Med Educ 2011; 2:70-3.

15. Murphy RJ, Gray SA, Straja SR, Bogert MC. Students' learning preferences and teaching implications. J Dent Educ 2004; 68(8):859-66.
16. Baykan Z, Nacar M. Learning styles of first-year medical students attending Erciyes University in Kayseri, Turkey. Adv Physiol Educ 2007; 31:158-60.

17. Wehrwein E, Lujan H, DiCarlo S. Gender differences in learning style preferences among undergraduate physiology students. Adv Physiol Educ 2007; 31:1537.

\section{AUTHORSHIP AND CONTRIBUTION DECLARATION}

\begin{tabular}{|c|l|l|l|}
\hline Sr. \# & \multicolumn{1}{|c|}{ Author-s Full Name } & \multicolumn{1}{|c|}{ Contribution to the paper } & Author=s Signature \\
\hline 1 & Muhammad Azeem & Written the manuscript. \\
2 & Momina Akram & $\begin{array}{l}\text { Data analysis, Written the } \\
\text { manuscript. } \\
\text { Data recording \& analysis. }\end{array}$ \\
\hline 4 & Rubbab Asghar & Arfan ul Haq & Critically reviewed the article. \\
\hline 5 & Nadeem Tarique & $\begin{array}{l}\text { Data analysis, Critically reviewed } \\
\text { the article. } \\
\text { Critically reviewed the article. }\end{array}$ \\
\hline 6 & Saadia Ata & & \\
\hline
\end{tabular}

